"Determinants of capital structure of Spanish firms: the case of listed companies in time of crisis"

AUTHORS Natividad Rodríguez-Masero

ARTICLE INFO

DOI

Natividad Rodríguez-Masero (2016). Determinants of capital structure of Spanish firms: the case of listed companies in time of crisis. Investment Management and Financial Innovations, 13(1), 32-48. doi:10.21511/imfi.13(1).2016.03

http://dx.doi.org/10.21511/imfi.13(1).2016.03

RELEASED ON

Friday, 04 March 2016

JOURNAL

"Investment Management and Financial Innovations"

FOUNDER

LLC "Consulting Publishing Company "Business Perspectives"

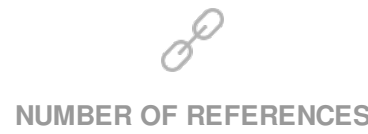

0
NUMBER OF FIGURES

0

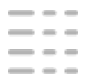

NUMBER OF TABLES

0

C The author(s) 2021. This publication is an open access article. 
Natividad Rodríguez-Masero (Spain)

\title{
Determinants of capital structure of Spanish firms: the case of listed companies in time of crisis
}

\begin{abstract}
The aim of this paper is to provide new empirical evidence on the capital structure of companies. The author is going to analyze models used in previous literature, and these models will be applied to the sample selected. This sample is different from previous ones in time and characteristics. So it can be analyzed whether the type of company and the moment of time affect the financial structure of models. At the same time the author offers a new model that is representative of the variables that affect the corporate debt in this type of firms.

Methodologically a multivariate analysis has been used with panel data on a sample of Spanish listed companies for the period 2003-2013. The sample had not been used in previous studies and the time horizon is characterized by periods of both boom and difficulties and even crises in corporate finance. First the author analyzes a series of models developed from previous studies in which different variables are analyzed, on the other hand has been discussed a proposed based on the results observed model. It is also reported about the evolution of the debt and the level of intangibles by the industry.
\end{abstract}

The results are consistent with the existence of influence of variables related to economic structure (non current assets and current assets), the size of the company, the industry, the level of intangible assets and the return on the debt level.

Keywords: debt structure, Spanish quoted firms, panel data, financial crisis.

JEL Classification: G32, G3.

\section{Introduction}

Companies can access many sources of funding, both internal and external. The characteristics of each of the companies influence their choice of funding sources and the conditions in which they can access each type of financing. This requires a detailed analysis of the variables determining the financial structure that allows us to identify to what extent the individual business characteristics influence the choices for sources of funding.

Both the debt and the cost of capital carried by businesses affect their valuation. Factors such as debt, cost of capital and the average cost of borrowed funds, as well as their own resources, must be taken into account in calculating the value of the company. A company that relies on higher cost funding will ultimately show a lower company value. Therefore, debt plays an integral role in reliable business valuation.

The corporate capital structure has been studied in numerous writings. Many are based on the works of Modigliani and Miller (1958) which have influenced many subsequent studies, as well as this paper, which highlights the role of financial structures and economic decisions of each company and how it directly relates to their economic survival.

The basis of most studies that attempt to explain the determining factors of borrowing or financing by businesses like this work, begin with Modigliani and

(c) Natividad Rodríguez-Masero, 2016.

Natividad Rodríguez-Masero, Department of Finance and Accounting, University Pablo de Olavide of Seville, Spain.
Miller (1958). This work evaluates the capital structure of firms in perfect markets. Studies of other authors such as Myers (1984) and Myers and Majluf (1984) continue to advance the study of the capital structure of the companies in imperfect markets. Additionally, Modigliani and Miller (1963) and Miller (1977) analyze the change in value from issuing debt to retire unleveraged equity. Hull (2007, 2010) extends this research by developing the Capital Structure Model that demonstrates how the costs of borrowing and growth affect leverage. Later, this author includes a leveraged situation to the prior research where wealth transfers between existing equity and debt owners can result from a leverage change, that is needed to maximize firm value (Hull, 2012). Finally, Hull (2014) includes the tax rate changes in the analysis.

Other authors analyze borrowing based on variables such as the sector, size or intangible assets (Long and Malitz, 1985; Jimenez and Palacín, 2006; Masero-Rodríguez et al., 2013). These different approaches provide us with a broader view of the contributions that are in this field of work.

In recent years, the global financial system has gone through a major crisis, which has had an impact on all markets and has affected the availability of credit offered by financial institutions (Ayuso, 2013). This is an example of how a change in one sector in the financial industry directly impacts the companies that are highly dependent on securing borrowed funds as opposed to companies that rely on internal sources of financing and self-financing. Understanding the funding sources of each company and their individual financial decisions will factor 
directly into their capital structure and determine the economic risk exposure of each type of business. In this regard it should be noted that exposure refers to exposure to risks arising from external financing for each of the companies.

There are partial theories that explain this debt based in certain circumstances or business characteristics (Myers, 2001). These partial theories analyze variables such as size, sector or asset composition and its influence on corporate borrowing. This paper covers variables already studied in previous works such as industry, used in Rodríguez-Masero et al. (2013), the size of the company (Jiménez and Palacin, 2006) or the level of intangibles (Long and Malitz, 1985), among others.

In light of the numerous works on the corporate debt, we will focus on current Spanish quoted firms to analyze previous proposals and compare the results with our own data to see the similarities and differences with conclusions obtained by previous works.

To study the determinants of the financial structure, we will analyze the characteristics of the selected sample companies, we will utilize their individual data for the timeframe 2003-2013 and determine the industry to which they belong. The usefulness of this type of analysis, following Oliveras and Moya (2005) is two-fold. It allows us to determine if the financial position of the company is consistent with the sector to which it belongs, and will allow us to predict the behavior of companies from the sectoral information.

In this paper we address the analysis of the capital structure of the companies listed on the Spanish Stock Exchange, for the period between 2003 and 2013, with attention to the dates of 2008-2013 which reflect the greatest effects of the economic crisis. In the sample we did not consider financial companies because of their complexity for comparison, as financial companies have specific accounting standards. In addition to this argument, we must note that financial institutions have experienced, in recent years many legislative changes and government oversight that has required industry restructuring and created significant volatility which complicates the prediction of the model and would require more extensive development particularly where regulatory changes occurred (Miralles and Daza, 2011). So we finally are going to consider 144 quoted firms.

This work raises a number of thoughts about the determinants of the financial structure of listed Spanish quoted companies and analyzes the influence these determinants have on their funding decisions. To achieve this we have to consider the financial structure, economic structure, investment and performance indicators of each company. We start from the assumption that the determinants of capital structure are within these magnitudes. The analysis also factors in the specific influences in each sector as it relates to financing decisions.

The structure of the paper is as follows: first we will analyze literature/theories expounded by previous works based on foreign companies. Also reviewed will be studies of the Spanish market to provide a comparison of companies in similar markets. Second, we describe the selected companies, in detail. The criteria and methodology used in selecting and obtaining the data will be explained. Thirdly we will explain the results of our analysis and compare this information with that obtained from other theoretical works. Fourth and finally, we will present our conclusions from the study.

\section{Theories on financial structure}

There are innumerable theories to analyze the determinants of capital structure of firms. We, therefore will focus on the most relevant.

Many studies have attempted to find the relationship between financing decisions and variables such as size, sector, capital structure, the tax deductions associated with external financing, etc. These variables are closely related and are dependent on the type of activities performed and by the company and the sector in which the companies operate. The interdependencies among the variables that characterize the company are major contributors in their decisions related to the financial structure of the company.

The basis of the vast majority of work on the structure of capital begin with the work of Modigliani and Miller (1958), which forms the basis for modern thinking on capital structure. They argue that in the absence of taxes, the costs of bankruptcy and asymmetric information, that is, in an efficient market, the value of a company does not vary depending on their funding. Based on this work, one would not consider the valuation of a company's financial structure. According to these authors, corporate taxes influence the decisions regarding companies' financial structure. The tangible influences include the costs of external financing and the weakening of the profits, before tax. The lack of factoring of the debt in the valuation of companies is not perfect.

In the same line is the writing of Kraus and Litzenberger (1973). This paper presents another important theory of financial structure of the company: The Trade-off Theory argues that there is an optimal capital structure for each company, that 
is, a combination of debt and equity that maximizes the value of the company and minimizes the average cost of its resources. Therefore, company decisions regarding funding will depend on the interaction of competitive forces such as tax reporting or tax advantages, debt financing and potential costs arising from business failures.

In connection with the costs of bankruptcy, Castanias (1983) conducted a study that tries to find evidence to support or refute the hypothesis that these costs and tax deductions for financial debt significantly influence the choice of capital structure. This work has a limitation as it focuses on smaller companies and other studies. The conclusion reached by the study is that companies seek a proportionate share of debt and equity to enable them to achieve a balance between optimizing deductions for external financing and bankruptcy costs. That is, this study rejects the hypothesis of Modigliani and Miller (1958) that debt does not affect the valuation of companies and supports the idea that the deductions and bankruptcy costs are decisive factors when resorting to other type of financing.

Following the analysis of the impact that taxes have on the choice of financing, Myers (1984) based on the ideas of Modigliani and Miller, introduces the tax effects associated with debt financing and bankruptcy costs in explaining the financial structure of firms. In this paper (Myers, 1984) two theories of capital structure are analyzed: first the Theory of Optimal Financial and secondly, the Theory of Order of Preference or Pecking Order Theory. Myers says that The Theory of Optimal Financial applies somewhat but has a coefficient of determination $\left(\mathrm{R}^{2}\right)$ very low, this motivates to seek a new model based on asymmetric information, which adds the elements of trade-off theory having empirical support. Based on this model, Myers provides a set of principles or theories as to how firms choose their capital structure. For example, if a company seeks cover part of their investment with new debt, they will be mindful of the risk of bankruptcy or insolvency and choose primarily less risky options.

In contrast to what was proposed by Modigliani and Miller (1958), authors, Myers and Majluf (1984) base their premises on the existence of asymmetric information in capital markets and among businesses, i.e., on the premise that capital markets are not perfect. These authors suggest that to minimize the costs associated with this asymmetric information and derivative transactions, firms tend to choose different means of financing in sequence. The proposed sequence is as follows: first, firms would choose to self-finance, that is financing new investments through internally generated resources. Second, companies would resort to debt without risk or low risk of market exposure, i.e., bank financing. Lastly, companies would choose debt risk or increased risk of exposure and ultimately would choose to be financed through the issuance of shares. This theory is based on four pillars:

- Companies prefer internal financing.

- Dividend distribution adapts to investment opportunities.

- Dividend distribution is more or less fixed in the short term, given that fluctuation in profitability and opportunities can not be foreseen, internal cash flows may be higher or lower than the cost of capital.

- If external funding is obtained first the safer securities are chosen.

Moreover, Bradley et al. (1984) analyzed the literature on capital structure, and made a contrast with existing theories. The results suggest that the Financial Hierarchy Theory mentioned has a greater validity than the Target Adjustment Model, which is a Target Adjustment Model based on target variables in relation to the indebtedness to which companies would have to tender. According to this theory the firm sets an optimal level of debt and the decisions made regarding the choice of funding factor in their determination of the optimal level of debt. They also noted that managers of firms in the sample spent less effort in determining their defined optimal debt ratio.

The work of Myers (1984) and Myers and Majluf (1984) is based on the Theory of Financial Hierarchy, which according to Fernández et al. (2004) argues that adverse selection problems lead firms to prefer internal financing to external, but when external funding is needed the issuance of shares has increased associated costs. Many authors have tested this theory in different samples, this work (Fernández et al., 2004) is an example. For a sample of eighty-five Spanish listed companies for the period between 1995 and 2002, this paper confirmed that the financing decisions of Spanish firms were successfully explained by the theory of financial hierarchy (Fernández et al., 2004).

Other authors who use external company factors, such as asymmetric information, are Harris and Raviv (1991). They analyze the capital structure based on agency costs, asymmetric information, market interactions and corporate control, to determine that the capital structure is more similar between industries than between companies in different sectors. In this paper they analyze many factors that influence corporate financing. Harris and Raviv reviewed the related literature on capital 
structure and found a number of studies that agree that debt increases as a result of factors such as fixed costs, growth opportunities, size of the company and the tax deductions for debts, while debt decreases with volatility, advertising expenditures, expenditures for research and development, the probability of bankruptcy, profitability and product differentiation that market.

\section{Theorical framework}

In this section, we are going to explain the international cases in chronological order and finally we will also analyze the Spanish cases. To focus on the analysis of debt we delve into the proposals of the principal authors on this subject and compare their theories with our selected sample. Thus, from the point of view of investment, Long and Malitz (1985) analyzed the relationship between the financial structure of the companies and their investment decisions. The conclusion is that the debt depends on the volume of business investment in tangible assets or intangible capital assets or specified assets of the company. That is, according to these authors the type of investment made by the company determines the funding source to which recourse. This is because the companies investing in intangibles have greater difficulty accessing external funding due to higher agency costs incurred. These major problems of access to external financing arise as intangible assets are usually specific to a particular company, that is, only generate profitability for that particular company.

From the point of view of liability Marsh (1982) this work discusses how firms choose between different financial instruments based on past costs of debt. First, it shows that market conditions significantly influence the debt and past costs between debt and equity. Furthermore, according to the author, the decisions seem guided by an objective debt, based on the results of this work which would be influenced by the size of the company level, the composition of assets and bankruptcy costs.

Moreover, among the key findings of Titman and Wessels (1988) are that firms with more diversified lines of business are less indebted as they may impose higher costs on to their customers, employees and suppliers in the event of liquidation, and that transaction costs significantly affect the structure of capital. There is a negative relationship between the ratios of short-term debt and the size of the companies that may be related to higher transaction costs borne by small businesses, a negative relationship between indicators of past profits and current levels debt. The study supports therefore the theories of Myers and Majluf.
In the study of debt, it is important to perform a data analysis that includes companies from various countries in order to study their differences and similarities. One of the papers that consider companies from multiple countries is Wald (1999). This study analyzed the factors related to the financial structure of companies in France, Germany, Japan, United Kingdom and United States. Although many similarities are found between countries, there are some significant differences. Specifically, the most significant differences are the ratios of long-term debt/assets and business risks, profitability, size and growth. These correlations can be explained by tax differences between countries and agency costs, variables previously discussed. The study concludes that both institutions and agency problems significantly influence the capital structure of firms. Therefore firms with similar characteristics that are from different countries may have different capital structures, according to this work. That is, this paper argues that firms with similar characteristics but located in different countries have different capital structure due to differences in institutions and agency problems.

Finally, to conclude, the work of Myers (2001), which examines some of the most relevant existing theories so far and attempts to draw conclusions based on them. Previous studies have proven the importance of taxes, differences in information and agency costs in funding decisions, however companies with similar characteristics have different financial structures when, based on these similarities, should choose similar financing. Previous data are collected in the work of Rajan and Zingales (1995) that shows that debt ratios are low or negative when the profitability and business risks are high, or that intangible assets are often associated with lower debt ratios. Therefore, concluding the work, there is no general theory to explain the capital structure of firms.

Most studies mentioned generally focus on AngloSaxon countries in the United States market. To broaden our analysis to include the Spanish market, we reviewed the work of Sánchez-Vidal and Marín (2005). This work analyzed whether the implications of the Theory of Hierarchy are met in the Spanish market. They analyzed a number of companies for 1993-2000. This study shows that the assumptions of the theory of the Hierarchy for midsize companies are met. However the assumptions are not met in large and small sized companies who rely primarily on capital as a means of funding. This could be because, in small businesses, funding needs could be met by new contributions of principles and/or family members. 
In the Spanish case and following the Spanish industrial companies, Mato (1990) discusses the debt policies of firms with a sample of 521 industrial firms for the period 1982-1985. This work continues in the line of previous works, such as Mato (1988) and Mato (1989) and observes the influence of self-financing companies and their investment decisions and the effect of financial structure. The paper concludes that with respect to the effect of variables that reflect greater financial pressure associated to the debt, there is a negative effect of the average cost of borrowed funds and a positive effect on the relative weight of the physical assets in total assets. Moreover, the financing needs of the investment and dividend payments are covered, according to the author, usually through increased borrowing. This would be in line with the theory of financial hierarchy.

The work of Fariñas and Suarez (1996) focused on industrial companies, analyzing the financial structure, the annual flows of financing and their costs. The sample analyzed consists of a set of Spanish industrial firms from the 1990s. The conclusions are consistent with the existence of heterogeneity among firms, and therefore would not be a determining factor when choosing the type of financing. Specifically, for the period 1991-1994 industrial enterprises were found to be financed $80 \%$ by short-term resources, primarily by providers in terms of long-term debt, and $56 \%$ primarily financed through credit institutions. The size of the company, does effect the financial structure as smaller companies are turning less to banking resources, both short and long term, while the cost to support these small businesses is higher (about 2 points) than larger companies.

Meanwhile, Andrés-Alonso et al. (2000) analyze the debt in the Spanish case for 1991-1995. They try to observe the relationship between borrowing decisions and capital structure on the market value of companies listed on the Madrid Stock Exchange for this period. The results of this study are consistent with the existence of a positive relationship between leverage and value creation for companies with no growth opportunities. Debt has a "disciplinary" effect or correction for this type of business, minimizing the problems of over investment. For companies with growth opportunities this debt causes firms renounce these growth options, i.e., there is a negative relationship in this case (underinvestment problem). In addition, the distorting effect of the separation between ownership and management on the efficient allocation of resources supports the non-neutrality of debt with the structure of ownership and control.
Another work in the Spanish field that focuses on a particular type of business is the de Segura et al. (2003) that analyzes the Spanish manufacturing firms for the period 1991-1998. This paper found evidence that confirms that smaller firms have higher debt and higher cost of debt. It is observed that there is greater reliance on external financing for industrial firms and that borrowing is primarily short term. Regarding the cost of debt, they find evidence that size is a variable that credit institutions contemplated in determining the costs associated with financing provided (premium over the interbank rate). On the other hand, companies engaged in intensive technologically innovative activities have a more favorable structure and other financial costs.

The work of Acedo et al. (2005) focuses on companies in the community of La Rioja, mostly SMEs for the period 1995-2000. Companies in this location were analyzed by their economic and financial performance, debt and the cost of debt. They found an inverse relationship between firm size and debt and cost of debt.

The Spanish paper by Jimenez and Palacín (2006), has two distinct features as it is based on a set of Andalusian companies therefore acting within the Spanish market, and it uses more current data from 2001. This paper analyzes variables such as firm size to conclude that size is a decisive factor when choosing short-term external financing. However, the effect is not significant for long term external financing. The work also analyzes relationships in the debt-sector activity reaching the conclusion that the sector significantly affects the level of debt and its composition, which means that the financial structure may not be optimal.

Another work that analyzes the industry's influence in the capital structure is RodríguezMasero et al. (2013) which further studies the effects of the recent crisis in the choice of business financing. This study analyzes a sample of 70 companies listed on the Madrid Stock Exchange for the period 2006-2011. The choice of funding sources is found to have a significant influence in the sector. It is also noted that the financial crisis has affected the financing decisions of firms. These results show the high heterogeneity indicated by the work of Farinas and Suarez (1996), which may be due to different sample selected or the convergence between the characteristics of the firms in the industry in recent years.

The most recent study reviewed is Menendez and Mendez (2013) on the evolution of borrowing by non-financial Spanish companies since the beginning of the crisis. This paper seeks to analyze 
the behavior of firms to identify differences by sector, size and the degree of leverage. The results show that the energy sector has the higher level of debt, while the debt ratio (defined as the ratio of total debt to cost between net assets) is the largest in the construction sector for the same time period. In terms of size, large firms have the highest level of debt and debt ratio presented for the entire period. The evolution of the amount debt from 2009 is decreasing. However, larger companies began to egress from 2010. Based on the results, there appears to be a relationship between the level of initial debt (2007) and its evolution. This relationship is also observed in the debt ratio.

The conclusion of the work of Menendez and Mendez (2013) is that, since 2009, there has been a process of deleveraging focused on companies that had higher debt rates and needs to have reached its highest debt levels. Also, the activity of these companies shows that the most indebted are those that have experienced a more unfavorable templates and investment in tangible fixed assets, i.e. they have been more affected. This shows how in the introduction about the justification of the work based on the exposure of the most indebted companies.

There are works that focus on specific market sectors, such as Gude (2014) which analyzes the bottled water industry and Spanish debt determinants present. This paper concludes that the main determinant of borrowing by companies in this sector is the inverse of "firmness ratio" which is calculated as the division between noncurrent assets and liabilities, followed by liquidity and financial stability and finally the economic structure and rotation. This work also shows that, in terms of economic structure the proportion of fixed assets to total assets and debt are related in a positive direction. The rationale for this relationship is the work that the plant represents a guarantee of payment to creditors.

\section{Methodology}

This work is based on evaluating a sampling of Spanish companies listed on the Madrid Stock Exchange. This enhanced reliability is due in part to their regular auditing practices and the annual filing of financial statements in the Comisión Nacional del Mercado de Valores (CNMV), Spanish SEC which provide important investor information. We will use data from these companies corresponding to the specific time period that has not been part of a prior study.

Although the data would be available in the National Securities Market Commission, we are going to use the accounting data of the SABI
(Analysis System of Iberian Balance), which is a database that allows information to search on a large number of Spanish and Portuguese companies.

The sample was composed of 144 companies, because it has been excluded from the analysis of the financial sector companies as they are governed by a different accounting rules, causing the financial structure of this sector of businesses their balance of these businesses to differ from the rest of firms considered.

The period for which we will perform the analysis is 2003-2013 and we want to test whether firms always have the same capital structure regardless of the economic situation and the crisis affecting their funding. We believe that the selected sample is of sufficient size to draw conclusions and provides an approximation to the expected behavior of other companies in the sector. The methodology used panel data (Montero, 2011) because it allowed us to combine information from several companies for each year during the period 2003-2013.

The economic and financial data on which we will base our work are related to the capital structure, economic structure and profitability of each of the companies. We obtained data from Balance Sheet, Income and Cash Flow Statement.

The dependent variable is the level of debt:

- Debt ratio (L): it is given by the ratio of the indebtedness of the company's total assets, i.e., is calculated as total liabilities divided by total assets.

The independent variables included in the study are as follows:

- ROA (Titman and Wessels, 1988; Rajan and Zingales, 1995; Gil de Albornoz and Giner, 2013): a ratio that reflects the profitability of the business, i.e., is the result of dividing operating income by total assets.

- Liquidity ratio (Marsh, 1982; Long and Malitz, 1985; Gil de Albornoz and Giner, 2013) calculated in this case as the split between current assets and current liabilities, i.e., indicating the proportion of liquid liabilities covered by liquid assets.

- The size, calculated using the natural logarithm of total assets (Marsh, 1982; Long and Malitz, 1985; Titman and Wessels, 1988; Fariñas and Suarez, 1996; Jimenez and Palacín 2006).

- The proportions of current assets and intangible assets of total assets (Marsh, 1982; Long and Malitz, 1985).

- The equity, liabilities and current liabilities (Jimenez and Palacín, 2006).

- The cost of debt (Kd) (Mato, 1990).

- Physical assets (Mato, 1990). 
- Sector, based on the classification followed by the Madrid Stock Exchange (Jimenez and Palacín, 2006).

- The indebtedness of the previous year (LLAG) (Menéndez and Mendez, 2013).

As we mentioned earlier in the methodology we use panel data, for the period from 2003 to 2013 . The aim of the paper is to analyze the corporate borrowing through a series of pre-defined variables, for this we first make a comparison of our sample with the models presented by other authors who understand accounting collect as much information, then propose a model in based on the results obtained.

In our analysis we use the technique OLS pooled with dummy variables, allowing us to collect individual data on each company during the specified time period. In addition, we also apply the fixed effects model, because this model analyzes the impact of variables that vary over time, to those cases for which there is no correlation between individual effects and the explanatory variables. We then contrast the results using the random effects model; this model assumes the independence between error terms and explanatory variables. To decide between fixed or random effects we have run the Hausman test because it is performed to validate the exogeneity of the firm specific effect with dependent variables. In this case we can decide which may be random or fixed and decide as well if the null hypothesis is that the preferred model is random effects versus the alternative the fixed effects. If the null hypotheses are rejected, then the fixed effect model will be retained.

From the studies previously analyzed many variables are extracted that could explain their choice of financial structure of the companies. The selected variables are collected in Table 1.

Table 1. Explanatory variables

\begin{tabular}{|l|l|l|}
\hline \multicolumn{1}{|c|}{ Variables } & \multicolumn{1}{c|}{ Explanation } & \multicolumn{1}{c|}{ Calculation } \\
\hline L & Debt & Total liabilities/total assets \\
\hline SIZE & Company's size & Neperian logarithm of total assets \\
\hline Sector & Sector & \\
\hline ROA & Return over asssets & Data from SABI database \\
\hline LIQ & Liquidity rate & Current assets/liabilities \\
\hline FA & Fisical assets complementary of IA, (Mato, 1990) & (1-Intangible assets/total assets) \\
\hline IA & Proportion of intangible assets & Total intangible assets/total assets \\
\hline NCA & Proportion of non-current asset & Non-current asset/total asset \\
\hline CA & Proportion of current asset & Current asset/total asset \\
\hline NCL & Non-current liabilities & \\
\hline CL & Current liabilities & \\
\hline
\end{tabular}

In addition to the analyzed variables they contemplate other variables such as taxes, operating cash flow and financial structure. We have taken these for comparison with models made by other authors in this paper as applied to the sample selected the most significant regressions proposed in the literature. These models allow us to study the relationship between the variables, and compare the results obtained from our data with those obtained previously.

\section{Analysis and results}

To analyze the determinants of the financial structure of Spanish listed companies we extracted the data for our analysis from the SABI database and the National Commission of the Stock Exchange.

In this paper we will also include an analysis of the influence of the specific business sector and the level of debt. We will utilize the sectorial classification proposed by the Madrid Stock Exchange (see Apendix 1).
We created dummy variables that reflect the year analyzed and their influence on the level of indebtedness of the company. A dummy variable is a variable that is introduced into the model to include qualitative variables in the analysis. In our case we introduce the account for the year under consideration. In this way we increase the significance and results of the model.

The sample analysis will focus on two points of view. The first will check the relations proposed by the studies discussed in the third section, our sample is different from previous ones in time and characteristics. So we can analyze whether the type of company and the moment of time affect the financial structure of models. At the same time we offer a new model that is representative of the variables that affect the corporate debt in this type of firms. So, the second point of view will be to establish a model that reflects the movements of the variables used above, and analyze the results obtained with the different samples used. 
It should be noted that among the studies discussed are no coincidences regarding the variables analyzed so that we will jointly analyze the jobs with similar variables.

First we will study the preliminary question of how it influences the economic structure of the company and the size of it in its debt policy and the type of investment. This information will then be compared with results of other authors.

Long and Malitz (1985) proposed that there was a relationship between the financial structure of the company and its type of investment, thus if the company assets included a higher proportion of intangibles, it was more difficult to secure external financing and therefore, external debt was lower. These authors proposed two samples, whose companies are based on the same baseline, the model starts from the assumption that these firms operate in perfect capital markets. The results obtained by Long and Malitz (1985) indicate that there was a relationship between leverage and the type of assets that makes business investment.

Second, with regard to the economic situation, Marsh (1982) discusses the influence of firm size and composition of assets in debt. The results show that the debt is influenced by the composition of the assets, the size of the company and bankruptcy costs.

First we present a model (Model I) containing equivalent to those provided by these authors variables. The equation proposed is as follows.

$L_{i t}=\beta_{0+} \beta_{1} S I Z E_{i t}+\beta_{2} I A_{i t}+\beta_{3} L I Q_{i t}+\beta_{4} C A_{i t}+\beta_{5}$ year $_{i t}+\varepsilon_{i t}$ (Model I),

where $S I Z E_{i t}$ represents the size of the assets of firm $i$ in year $t, I A_{i t}$ reflects the proportion of intangible assets of firm $i$ in year $t, L I Q_{i t}$ reflects the proportion of current assets over current liabilities of firm $i$ in year $t, C A_{i t}$ is the proportion of current assets of total assets of firm $i$ in year $t$.

This investment model used by Long and Malitz (1985) have shown for the proportion of current assets and we have also included the proportion of intangible assets. The size of the company used by Long and Malitz (1985) and Marsh (1982) is represented by SIZE. The model results are found in Table 2 we have not considered non-current assets variable because of the existence of multicollinearity between this variable and current asset variable can distort predictions.

Table 2. Regression results, Model I

$L_{i t}=\beta_{0}+\beta_{1} S I Z E_{i t}+\beta_{2} I A_{i t}+\beta_{3} L I Q_{i t}+\beta_{4} C A_{i t}+\beta_{5}$ year $_{i t}+\varepsilon_{i t}$

\begin{tabular}{|c|c|c|}
\hline$L_{\text {it }}$ & Coef. & $P>[t]$ \\
\hline$S I Z E_{i t}$ & 0.1763963 & 0.055 \\
\hline$I A_{i t}$ & $-6.65 \mathrm{e}-08$ & 0.440 \\
\hline$L I Q$ & -0.0018288 & 0.003 \\
\hline$C A_{i t}$ & 1.443835 & 0.000 \\
\hline yr2004 & -0.3831607 & 0.777 \\
\hline yr2005 & -0.7860714 & 0.576 \\
\hline yr2006 & -0.3947389 & 0.701 \\
\hline yr2007 & -0.3712641 & 0.720 \\
\hline yr2008 & -0.3807109 & 0.711 \\
\hline yr2009 & -0.2599159 & 0.799 \\
\hline yr2010 & -0.2925424 & 0.776 \\
\hline yr2011 & -0.0595141 & 0.955 \\
\hline yr2012 & 0.3292365 & 0.778 \\
\hline yr2013 & -0.2793532 & 0.786 \\
\hline _cons & -1.634066 & 0.215 \\
\hline Number of obs & \multicolumn{2}{|c|}{1234} \\
\hline $\mathrm{F}(14,1219)$ & \multicolumn{2}{|c|}{5.01} \\
\hline Prob $>F$ & \multicolumn{2}{|c|}{0.0000} \\
\hline R-squared & \multicolumn{2}{|c|}{0.6667} \\
\hline
\end{tabular}

Notes: This table reports OLS pooled regression of the model. Where $L_{i t}$ represents the debt ratio of the firm $i$ at time $t$, $C A_{i t}$ represents the proportion of current assets of the firm $i$ at time $t, S I Z E_{i t}$ represents the logarithm of total assets of firm $i$ at time $t, I A_{i t}$ represents the proportion of intangible assets and the $L I Q$ ratio represents the liquidity rate of the firm $i$ at time $t$.

So we can conclude that there is a positive relationship between the size and the level of debt, also there is a positive relationship between the current assets and the level of debt. However there is a negative relationship between the intangible assets and the liquidity. The descriptive statistics and the correlation matrix are presented in Tables 4 and 5 respectively. 
Table 3. Descriptive statistics, Model I

\begin{tabular}{|l|c|c|c|c|c|}
\hline \multicolumn{1}{|c|}{ Variable } & Observations & Mean & Standard deviation & Minimun & Maximum \\
\hline$L_{i t}$ & 1428 & 0.7596 & 2.5828 & 0 & 43.7758 \\
\hline$C A_{i t}$ & 1439 & 0.3698 & 0.2783 & 0 & 1 \\
\hline$S I Z E_{i t}$ & 1442 & 12.5952 & 2.0881 & 6.3886 & 18.3494 \\
\hline$I A_{i t}$ & 1328 & 0.0331 & 0.1136 & 0 & 2.1755 \\
\hline$L I Q_{i t}$ & 1320 & 96.7455 & 140.1001 & 0.027 & 970.842 \\
\hline
\end{tabular}

Notes: The sample is composed of 144 companies for the period 2003-2013 quoted in Madrid Stock Exchange. Where $L_{i t}$ represents the debt ratio of the firm $i$ at time $t, C A_{i t}$ represents the proportion of current assets of the firm $i$ at time $t, S I Z E_{i t}$ represents the logarithm of total assets of the firm $i$ at time $t, I A_{i t}$ represents the proportion of intangible assets and the $L I Q$ ratio represents the liquidity rate of the firm $i$ at time $t$.

Table 4. Correlation matrix, Model I

\begin{tabular}{|c|c|c|c|c|c|}
\hline & $L_{i t}$ & $S I Z E_{i t}$ & $I A_{i t}$ & $C A_{i t}$ & $N C A_{i t}$ \\
\hline$L_{i t}$ & 1.0000 & & & & \\
\hline \multirow{2}{*}{$S I Z E_{i t}$} & $0.0793^{*}$ & \multirow{2}{*}{1.0000} & & & \\
\hline & $(0.0027)$ & & & & \\
\hline \multirow{2}{*}{$I A_{i t}$} & $0.05570^{*}$ & 0.0357 & \multirow{2}{*}{1.0000} & & \\
\hline & $(0.0000)$ & $(0.1940)$ & & & \\
\hline \multirow{2}{*}{$C A_{i t}$} & $0.0563^{*}$ & $-0.2610^{*}$ & 0.0034 & \multirow{2}{*}{1.0000} & \\
\hline & $(0.0334)$ & $(0.0000)$ & $(0.9007)$ & & \\
\hline
\end{tabular}

Notes: Table 4 presents Pearson correlations, $p$-values are given in parenthesis. All variables are as defined previously, the number of observations is 1320 . The significance level is $* p \leq 0.01$.

In this case the correlation between the variables is expected and there is an average debt of $75.96 \%$, however, the minimum of this variable is 0 , that is because there are companies which do not have data in a particular year. The average of current assets is $36.98 \%$ and intangibles are around 3\%. The adjusted $\mathrm{R}^{2}$ is $66.67 \%$ this indicates that the model is significant and therefore we can conclude that there is a relationship between size and debt and between investment, which in our case is represented by the proportions of current assets and intangible assets, and the financial structure of the company, as proposed by Long and Malitz (1985) and Marsh (1982).

Taking into account the results obtained it should be noted that the relationships proposed by these authors are met. By the investment side we see that current assets variable is significant at $99 \%$ and the level of $100 \%$ intangibles. Regarding the size, the significance is $90 \%$. Therefore, the conclusions drawn by the authors in their work on the determinants of debt (Long and Malitz, 1985; Marsh, 1982) remain today and are valid for our sample data. This means that Spanish companies are influenced by their funding strategies indicators of liquidity, size and economic structure. In spite of the results obtained we have also taken into account the composition of intangible assets, it is very important and varies from company to company, some will attempt to highly value intangible market making it easy to exercise to guarantee to a loan or otherwise may have little value to an endorsement.

On the other hand, and following the model proposed by in Palacín and Jiménez (2007), we are going to suggest the Model II where the debt level is related to the size of the company and the sector.

$L_{i t}=\beta_{0}+\beta_{1}$ Sector $_{i t}+\beta_{2}$ SIZE $_{i t}+\beta_{3}$ year $_{i t}+\varepsilon_{i t}$, (Model III)

where Sector $_{i t}$ represents the sector to which firm $i$ belongs at time $t, S I Z E_{i t}$ represents the size of the assets of firm $i$ in year $t$.

Partial regressions debt-size, size-structure, the collected financial are in Tables 5 and descriptive statistics and the correlation matrix in Tables 6 and 7 respectively.

Table 5. Regression results, Model III

$L_{i t}=\beta_{0}+\beta_{1}$ Sector $_{i t}+\beta_{2}$ SIZE $_{i} t+\beta_{3}$ year $_{i t}+\varepsilon_{i t}$

\begin{tabular}{|l|l|l|}
\hline \multicolumn{1}{|c|}{$L_{i t}$} & Coef. & P $>$ [t] \\
\hline Sectorit & 0.7053267 & 0.007 \\
\hline SIZE & -0.2487654 & 0.026 \\
\hline yr2004 & -0.2784251 & 0.898 \\
\hline yr2005 & -0.045644 & 0.984 \\
\hline yr2006 & -1.868381 & 0.267 \\
\hline yr2007 & -2.093412 & 0.196 \\
\hline
\end{tabular}


Table 5 (cont.). Regression results, Model III

\begin{tabular}{|l|c|c|}
\hline \multicolumn{1}{|c|}{$L_{\text {it }}$} & Coef. & P [t] \\
\hline yr2008 & -2.032321 & 0.209 \\
\hline yr2009 & -1.893182 & 0.244 \\
\hline yr2010 & -1.754345 & 0.287 \\
\hline yr2011 & -1.906423 & 0.241 \\
\hline yr2012 & -0.9965734 & 0.595 \\
\hline yr2013 & -2.106228 & 0.194 \\
\hline cons & 3.778102 & 0.049 \\
\hline Number of obs & \multicolumn{2}{|c|}{1438} \\
\hline F (12, 1425) & \multicolumn{2}{|c|}{0.82} \\
\hline Prob > F & \multicolumn{2}{|c|}{0.6260} \\
\hline R-squared & \multicolumn{2}{|c|}{0.0243} \\
\hline
\end{tabular}

Notes: This table reports OLS pooled regression of the model. Where $L_{i t}$ represents the debt ratio of the firm $i$ at time $t$, Sector represents the sector of the firm $i$ at time $t, S I Z E_{i t}$ represents the logarithm of total assets of the firm $i$ at time $t$.

Table 6. Descriptive statistics, Model III

\begin{tabular}{|l|c|c|c|c|c|}
\hline \multicolumn{1}{|c|}{ Variable } & Observations & Mean & Standard deviation & Minimum & Maximum \\
\hline$L_{i t}$ & 1428 & 0.7596 & 2.5828 & 0 & 43.7758 \\
\hline Sectorit & 1485 & 3.0034 & 1.6620 & 1 & 6 \\
\hline SIZE it & 1442 & 12.59522 & 2.0880740 & 6.388561 & 18.34939 \\
\hline
\end{tabular}

Notes: The sample is composed of 144 companies for the period 2003-2013 quoted in Madrid Stock Exchange. Where $L_{i t}$ represents the debt ratio of the firm $i$ at time $t$, Sector represents the sector of the firm $i$ at time $t, S I Z E_{i t}$ represents the logarithm of total assets of the firm $i$ at time $t$.

Table 7. Correlation matrix, Model IV

\begin{tabular}{|c|c|c|c|}
\hline & $L_{i t}$ & Sectorit & SIZE \\
\hline$L_{i t}$ & 1.0000 & & \\
\hline \multirow{2}{*}{ Sectort } & 0.0082 & \multirow{2}{*}{1.0000} & \\
\hline & $(0.7560)$ & & \\
\hline \multirow{2}{*}{ SIZE } & $0.0793^{*}$ & $-0.0612^{\star}$ & \multirow{2}{*}{1.0000} \\
\hline & $(0.0027)$ & $(0.0202)$ & \\
\hline
\end{tabular}

Notes: Table 7 presents Pearson correlations, $p$-values are given in parenthesis. All variables are as defined previously, the number of observations is 1438 . The significance levels is $* p \leq 0.01$.

The correlation between the level of debt (1) and size of the company (SIZE) is significant at $10 \%$.

Analyzing the debt-size above regression, we see that these variables are significantly related in a positive direction, i.e., the larger higher debt. The relationship with the sector is positive which is consistent with similar work.

This makes sense as more investment will require more funding, which may come from own resources or borrowed funds of the company or a combination of both.

Finally we analyze the work of Mato (1990) which finds a negative effect of the average cost of borrowed funds and a positive effect on the relative weight of physical assets relative to total investment.
So we propose Model III:

$L_{i t}=\beta_{0}+\beta_{1}$ Physical assets $_{i t}+\beta_{2} K_{i t}+\beta_{3}$ year $_{i t}+\varepsilon_{i t}$ (Model IV)

where Physical assets of firm $i$ at time $t, k d_{i t}$ represents the average cost of borrowed funds.

The results for our sample reflect a correlation of the proportion of physical assets and the average cost of borrowed funds, although the latter results are not significant for a significance level of $10 \%$. However, the resulting regression equation assigns a positive coefficient to variable physical assets, which would create a higher level of physical assets and a higher debt level for the business which is consistent with the work of Mato (1990).

Table 8 shows the results.

Table 8. Regression results, Model IV

$L_{i t}=\beta_{0}+\beta_{1}$ Physical assets $_{i t}+\beta_{2}$ RatioKd $_{i t}+\beta_{3}$ year $_{i t}+\varepsilon_{i t}$

\begin{tabular}{|c|c|c|}
\hline$L_{i t}$ & Coef. & $P>[t]$ \\
\hline Physical assets it & 0.8675823 & 0.031 \\
\hline $\mathrm{Kd}$ & -0.0016629 & 0.000 \\
\hline yr2004 & 0.0542587 & 0.000 \\
\hline
\end{tabular}


Table 8 (cont.). Regression results, Model IV

\begin{tabular}{|l|c|c|}
\hline \multicolumn{1}{|c|}{$L_{i t}$} & Coef. & $P>[t]$ \\
\hline yr2005 & 0.2662577 & 0.000 \\
\hline yr2006 & 0.2393385 & 0.220 \\
\hline yr2007 & 0.4673228 & 0.000 \\
\hline yr2008 & 0.5088481 & 0.000 \\
\hline yr2009 & 0.5183763 & 0.000 \\
\hline yr20100 & 0.5217831 & 0.000 \\
\hline yr2011 & 0.7333434 & 0.001 \\
\hline yr2012 & 0.7842175 & 0.002 \\
\hline yr2013 & 0.6521388 & 0.000 \\
\hline cons & -0.7754055 & 0.054 \\
\hline Number of obs & & \\
\hline F (10,748) & \multicolumn{2}{|c|}{761} \\
\hline Prob $>F$ & \multicolumn{2}{|c|}{0.} \\
\hline R-squared & \multicolumn{2}{|c|}{0.0093} \\
\hline
\end{tabular}

Notes: This table reports OLS pooled regression of the model. Where $L_{i t}$ represents the debt ratio of the firm i at time $t$, physical assets of firm $i$ at time $t, K d$ is the cost of capital of firm $i$ at time $t$.

The descriptive statistics and the correlation matrix are shown in Tables 9 and 10 respectively.

Table 9. Descriptive statistics, Model IV

\begin{tabular}{|l|c|c|c|c|c|}
\hline \multicolumn{1}{|c|}{ Variable } & Observations & Mean & Standard Deviation & Minimum & Maximum \\
\hline$L_{\text {it }}$ & 1428 & 0.7596 & 2.5828 & 0 & 43.7758 \\
\hline Physical assets it & 1328 & 0.9669 & 0.1136 & -1.1755 & 1 \\
\hline$K d_{i t}$ & 846 & 0.7150 & 15.0966 & 0 & 433.98 \\
\hline
\end{tabular}

Notes: The sample is composed of 144 companies for the period 2003-2013 quoted in Madrid Stock Exchange. Where $L_{i t}$ represents the debt ratio of the firm $i$ at time $t$, physical assets of firm $i$ at time $t, K d$ is the cost of capital of firm $i$ at time $t$.

Table 10. Correlation matrix, Model IV

\begin{tabular}{|l|c|c|c|}
\hline & $L$ & Act Fis & Ratio Kd \\
\hline \multirow{2}{*}{ Lit } & 1.0000 & & \\
\hline \multirow{2}{*}{ Physical assets it } & $-0.5570^{*}$ & \multirow{2}{*}{1.0000} & \\
\hline \multirow{2}{*}{ Kdit } & $(0.0000)$ & 0.0192 & \multirow{2}{*}{1.0000} \\
\cline { 2 - 4 } & -0.0204 & $(0.5974)$ & \\
\hline
\end{tabular}

Notes: Table 10 presents Pearson correlations, $p$-values are given in parenthesis. All variables are as defined previously, the number of observations is 761 . The significance level is $* p \leq 0.01$.

In view of the results we can say that the proportion debt and a positive effect of physical assets is met. of physical assets is significant at $95 \%$ while the Finally, Table 11 presents a summary of the main cost of debt is at $100 \%$. Also, note that the sign of findings of some of the earlier works referenced the effect proposed by Mato (1990), negative cost of above. With which we have received there.

Table 11. Results comparison

\begin{tabular}{|l|c|c|c|c|c|c|c|c|}
\hline \multicolumn{1}{|c|}{ Variable } & $\begin{array}{c}\text { Long \& Malitz } \\
(1985)\end{array}$ & $\begin{array}{c}\text { Marsh } \\
(1982)\end{array}$ & $\begin{array}{c}\text { Sánchez-Vidal } \\
\text { \& Marín (2005) }\end{array}$ & $\begin{array}{c}\text { Titman \& } \\
\text { Wessels (1988) }\end{array}$ & $\begin{array}{c}\text { Jiménez \& } \\
\text { Palacín (2006) }\end{array}$ & Mato (1990) & $\begin{array}{c}\text { Fariñas \& Suárez } \\
\text { (1996) }\end{array}$ & $\begin{array}{c}\text { Rodríguez- } \\
\text { Masero et al. }\end{array}$ \\
\hline Size & Yes & Yes & Yes & $\begin{array}{c}\text { Yes (short term } \\
\text { debt) }\end{array}$ & Yes & - & Negative relation & - \\
\hline Liquidity & - & Yes & - & - & - & - & - & - \\
\hline CA & - & Yes & - & - & - & - & - & - \\
\hline NCA & - & Yes & - & - & - & - & - & - \\
\hline ROA & - & - & - & Yes & - & - & - & - \\
\hline Sector & - & - & - & - & Yes & - & No determinant & Have influence \\
\hline Kd & - & - & - & - & - & Negative efect & + size - Kd & - \\
\hline Material assets & - & - & - & - & - & Positive efect & - & - \\
\hline $\begin{array}{l}\text { Intangible } \\
\text { assets }\end{array}$ & Yes & Yes & - & - & - & - & - & - \\
\hline
\end{tabular}

Notes: own elaboration. 
In summary, our data conclude that the variables; size, level of intangibles, liquidity ratio and indicators of asset structure significantly influence the debt. Therefore, our results are consistent with the work of Long and Malitz (1985), Marsh (1982), Sanchez-Vidal and Marin (2005), Titman and Wessels (1988) and Fariñas and Suarez (1996).

For some sectors the cost of debt, physical assets and the return on assets and the volume of physical assets influence the debt for our sample data. This supports the contributions of Jimenez and Palacín (2006), Mato (1990), Rodríguez-Masero et al. (2013) and Fariñas and Suarez (1996).

After analyzing the above models and comparing them with established samples, we will propose a model that reflects the most influential variables in the level of indebtedness of the company.

The proposed model relates the level of debt, measured by $L_{i t}$, with the economic structure of the company (proportion of current asset respect total assets), the level of Intangible Fixed Assets and Return on Assets (ROA). The choice of these variables is derived from the investment of the company and the guarantee of payment to the entity that provides external funding. This makes us curious as to the relationship that exists between indicators of the proportion of intangibles and the level of debt as well as the weight of assets over indebtedness. The importance of these variables and reason for their inclusion in the study of the determinants of debt is that the asset constitutes the economic structure of the company, i.e., the activity of the company is based on the investment for its activity. Without funding there is no investment and without investment there is no activity. Saying that it seems necessary to establish the relationship between these variables and analyze what kind of companies, in their asset composition, will be most indebted.

To analyze this relationship we apply one model (Model IV):

$L_{i t}=\beta_{0}+\beta_{1} R O A_{i t}+\beta_{2} C A_{i t}+\beta_{3} S_{Z I Z E}+\beta_{4}$ llag $_{i t}+$

$+\beta_{5} L I Q_{i t}+\beta_{6} I A_{i t}+\beta_{7}$ year $_{i t}+\varepsilon_{i t}($ Model V),

where $R O A_{i t}$ represents the profitability of firm $i$ at time $t$. According to the theories analyzed it is suggested a negative relationship between the leverage and the profitability. $C A_{i t}$ represents the proportion of current assets of firm $i$ at time $t$. In this case we suggest a positive relationship between this ratio and the level of debt. SIZE represents the size of firm $i$ at time $t$. Regarding the size, theories suggest a negative relationship respecting on the debt, i.e., it can be assumed that a higher company requires lower debt. $\operatorname{llag}_{i t}$ represents the debt level of firm $i$ at time $t-1$. The level of debt of previous year must be related positivity regarding to the debt of the current year. $L I Q_{i t}$ represents the liquidity ratio of firm $i$ at time $t$. Authors agree that more liquid is the company's minor debt necessary. $I A_{i t}$ represents the level of intangible assets of firm $i$ at time $t$. It dependends on the quality of intangible assets, so the sign could be positive or negative.

The statistical technique used in these models is the pooled OLS explained previously, but we will also use the fixed effects model and random effects to reinforce the significance and value of the results. To determine which of the two effects better explains the model we will use the Hausman test, in this case the null hypothesis is rejected, then the fixed model will be retained. We have also calculated a robustness check in order to evaluate the method of estimation used in our analysis. In this case we have taken the period of 2008-2013 as the crisis is an important factor to consider and has not been reflected in earlier works. A focus on the period of economic crisis and specific companies will establish a more accurate level of corporate borrowing in this period.

Tables 12 presents the results obtained.

Table 12. Regression results, Model IV

$L_{i t}=\beta_{0}+\beta_{1} R O A_{i t}+\beta_{2} C A_{i t}+\beta_{3} S I Z E_{i t}+\beta_{4}$ llag $_{i t}+$ $+\beta_{5} L I Q_{i t}+\beta_{6} I A_{i t}+\beta_{7}$ year ${ }_{i t}+\varepsilon_{i t}$

\begin{tabular}{|c|c|c|}
\hline $\begin{array}{l}\text { Independent } \\
\text { Variables }\end{array}$ & OLS pooled model & Fixed effects model \\
\hline$R O A_{i t}$ & $-0.0120813^{*}$ & $-.0088299^{*}$ \\
\hline$C A_{i t}$ & 0.0364855 & .4011597 \\
\hline$S I Z E_{i t}$ & $-0.0614607^{\star *}$ & $-.6215498^{*}$ \\
\hline $\operatorname{Llag}_{i t}$ & $0.1369357^{\star \star *}$ & $-.1049612^{\star * *}$ \\
\hline$L I Q_{i t}$ & $-0.001456^{* \star *}$ & $-.0006746^{\star *}$ \\
\hline$I A_{i t}$ & $-1.307673^{* * *}$ & $.5964468^{\star \star \star}$ \\
\hline yr2008 & -0.0188148 & .149129 \\
\hline yr2009 & -0.0192089 & .1684797 \\
\hline yr2010 & -0.0630412 & .0640768 \\
\hline yr2011 & 0.1191462 & .2659469 \\
\hline yr2012 & 0.2409792 & .2713612 \\
\hline yr2013 & -0.0087481 & .3960583 \\
\hline _cons & 1.608522 & 8.695456 \\
\hline Number of obs & 694 & 694 \\
\hline $\mathrm{R}^{2}$ ajust & \multicolumn{2}{|c|}{0.1546} \\
\hline $\mathrm{R}^{2}$ (within) & & 0.1879 \\
\hline $\mathrm{R}^{2}$ (between) & & 0.26 \\
\hline $\mathrm{R}^{2}$ (overall) & & 0.78 \\
\hline Prob $>\mathrm{F}$ & 0.0000 & 0.3979 \\
\hline Haussman & & 0.0002 \\
\hline
\end{tabular}

Notes: This table reports OLS pooled regression (I) and the fixed effects estimation (II) of the model. Where $L_{i t}$ represents the debt ratio of the firm $i$ at time $t, R O A$ represents the profitability of the firm $i$ at time $t, C A_{i t}$ represents the proportion of current assets of the firm $i$ at time $t, S I Z E_{i t}$ represents the logarithm of total assets of firm $i$ at time $t, L I Q$ ratio represents the liquidity rate of the firm $i$ at time $t, I A_{i t}$ represents the proportion of intangible assets and the $\operatorname{Llag}_{i t}$ represents the debt ratio of the firm $i$ at the beginning of year $t$. Significance levels are indicated as follow: * significant at $10 \%$ level, ** significant at $5 \%$ level and $* * *$ significant at $1 \%$ level. 
The adjusted $\mathrm{R}^{2}$ is $15.46 \%$ thus we can affirm that the model is significant.

Variables debt last year (LLAG), the ratio of intangibles to total assets (IA/TA), size (SIZE) and the ratio of current assets (CA/TA) are significantly related to positive borrowing, however, the return on assets (ROA), the liquidity ratio (LIQ) are significantly related to the level of debt in the opposite direction. Therefore, we can say that the higher the return on assets and the liquidity of the company, the lower the level of indebtedness of the company. Furthermore, we see that the level of indebtedness of an exercise is positively influenced by the level of the previous year.

We also obtained data correlations and descriptive statistics that are to be included in the analysis. First, with respect to the mean data, debt is around $75.96 \%$ for the total of firms covered. It is also observed that the average proportion of intangible to total is low, around 3.3\%. To better analyze this relationship intangibles-industry will use a Pivot Table from Excel to inform us of sectorial averages for the horizon.

The descriptive statistics and correlation matrix of these models are in Tables 13 and 13 respectively.

Table 13. Descriptive statistics, Model V

\begin{tabular}{|l|c|c|c|c|c|}
\hline \multicolumn{1}{|c|}{ Variable } & Observation & Mean & Standard deviation & Minimum & Maximum \\
\hline$L_{i t}$ & 1428 & 0.7596 & 2.5828 & 0 & 43.7758 \\
\hline$N C A_{i t}$ & 1439 & 0.6302 & 0.2783 & 0 & 0.9997 \\
\hline$C A_{i t}$ & 1439 & 0.3698 & 0.2783 & 0 & 1 \\
\hline$R O A_{i t}$ & 891 & 2.1189 & 22.3182 & -422.92 & 265.336 \\
\hline$S I Z E_{i t}$ & 1442 & 12.5952 & 2.0881 & 6.3886 & 18.3494 \\
\hline Llagit $_{\text {ilt }}$ & 1427 & 0.7601 & 2.5837 & 0 & 43.7758 \\
\hline$I Q_{i t}$ & 1320 & 96.7455 & 140.1001 & 0.027 & 970.842 \\
\hline
\end{tabular}

Notes: The sample is composed of 144 companies for the period 2003-2013 quoted in Madrid Stock Exchange. Where $L_{i t}$ represents the debt ratio of the firm $i$ at time $t$, Sector represents the sector of the firm $i$ at time $t, S I Z E_{i t}$ represents the logarithm of total assets of the firm $i$ at time $t$.

Table 14. Correlation matrix, Model V

\begin{tabular}{|c|c|c|c|c|c|c|c|}
\hline & $L_{i t}$ & $R O A_{i t}$ & $C A_{i t}$ & $S I Z E_{i t}$ & $L L A G_{i t}$ & $L / Q_{i t}$ & $I A_{i t}$ \\
\hline$L_{i t}$ & 1.0000 & & & & & & \\
\hline \multirow{2}{*}{$R O A_{i t}$} & $-0.2584^{*}$ & \multirow{2}{*}{1.0000} & & & & & \\
\hline & $(0.0000)$ & & & & & & \\
\hline \multirow{2}{*}{$C A_{\text {it }}$} & $0.0563^{*}$ & -0.0098 & \multirow{2}{*}{1.0000} & & & & \\
\hline & $(0.0334)$ & $(0.7711)$ & & & & & \\
\hline \multirow{2}{*}{ SIZE it } & $0.0793^{*}$ & $0.0680^{*}$ & $-0.2610^{*}$ & \multirow{2}{*}{1.0000} & & & \\
\hline & $(0.0027)$ & $(0.0424)$ & $(0.0000)$ & & & & \\
\hline \multirow{2}{*}{ Llag $_{i t}$} & $0.6622^{*}$ & $-0.2847^{\star}$ & 0.0324 & $0.0564^{*}$ & \multirow{2}{*}{1.0000} & & \\
\hline & $(0.0000)$ & $(0.0000)$ & $(0.2256)$ & $(0.0343)$ & & & \\
\hline \multirow{2}{*}{$L I Q_{i t}$} & $-0.0878^{*}$ & 0.0450 & $0.1252^{*}$ & -0.0388 & $-0.0636^{*}$ & \multirow{2}{*}{1.0000} & \\
\hline & $(0.0015)$ & $(0.2054)$ & $(0.0000)$ & $(0.1589)$ & $(0.0223)$ & & \\
\hline \multirow{2}{*}{$I A_{i t}$} & 0.5570 & 0.0270 & 0.0034 & 0.0357 & $0.3505^{*}$ & $-0.0817^{\star}$ & \multirow{2}{*}{1.0000} \\
\hline & $(0.0000)$ & $(0.4485)$ & $(0.9007)$ & $(0.1940)$ & $(0.0000)$ & $(0.0041)$ & \\
\hline
\end{tabular}

Notes: Table 14 presents Pearson correlations, $p$-values are given in parenthesis. All variables are as defined previously, the number of observations is 694 . The significance levels is $* p \leq 0.01$.

Regarding the behavior of waste, we have to test the two hypotheses, fixed or random behavior of waste effects. First, with respect to the fixed effects, indicating that the error can be broken down into two parts, one fixed and constant for all individuals, and the other, random. Second, the random effect is that there is no fixed part of the behavior. This model is more efficient but may be more biased than the fixed effects. To test whether our model is fixed or random effects we have to apply the Hausman test. This is a test that compares the estimates of the fixed effects model and the random and if it finds systematic differences between the two, i.e., consistent estimates (fixed effects) and efficient (random effects) are different. The more consistent model is the fixed effects model.

In our case, when performing the Hausman test using Stata in our sample data we can see that the resultant $p$-value is low, i.e., less than 0.05 . This implies that systematic differences are found, the hypothesis of equality is rejected and therefore it is a fixed effects model. This means that there exists a correlation between the error and the regressors. 
Results contrast with findings in other studies see, for example, as Jimenez and Palacín (2006) observed that the size variable influencing the corporate borrowing, particularly medium-sized companies had lower levels of debt than smaller ones. However, in their work contributions collected in both directions, in that small firms are less indebted (Mato, 1990; Otero and Fernandez, 2004) and that small firms are more indebted, such as work of Segura and Toledo (2003).

As mentioned before, these models do not give us enough information about the relationship between the sector and the level of intangibles, which would be useful in our analysis. We have thus developed a dynamic figure that relates to the intangible sector. (see Figure 1).

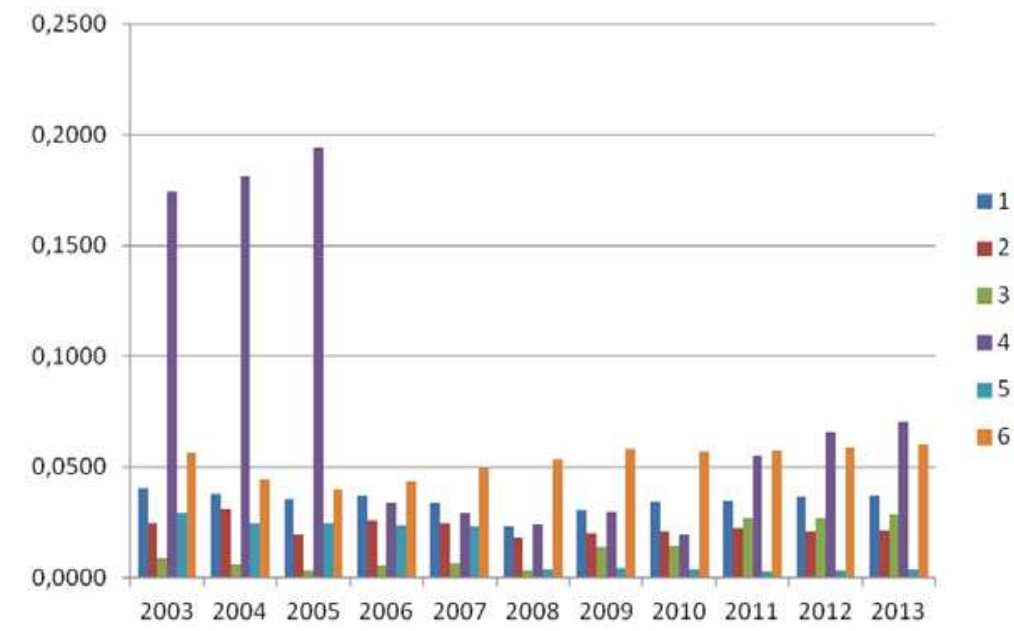

Sourse: own elaboration.

Fig. 1. Intangibles-sector

In this case we have chosen to analyze the ten year period from 2003-2013 to include the impact of the crisis on companies. On average, the Technology and Telecommunications (6) sector, had a higher proportion of intangibles. However, during the years 2003, 2004 and 2005, the Consumer Services sector exceeded other sectors as seen in Figure 1. It is also noted that the Financial Services and Real Estate sector (5) reports the lowest level of intangibles present since 2008, with a significant difference. Since 2008, the overall market trend is to increase the level of intangibles, this may be due to change in accounting standards. In other sectors the trend has been fairly consistent, no significant changes from one year to another are observed. The data are consistent with the type of industry, the level of intangibles of Technology and Telecommunications sector exceeds that of other sectors because it is a sector in which patents play a key role. An example of this is that within this sector are companies like Amadeus that provide technology solutions for the tourism sector.

In the same manner as intangible, we will analyze media data debt by sector. In Figure 2 we can see the data.

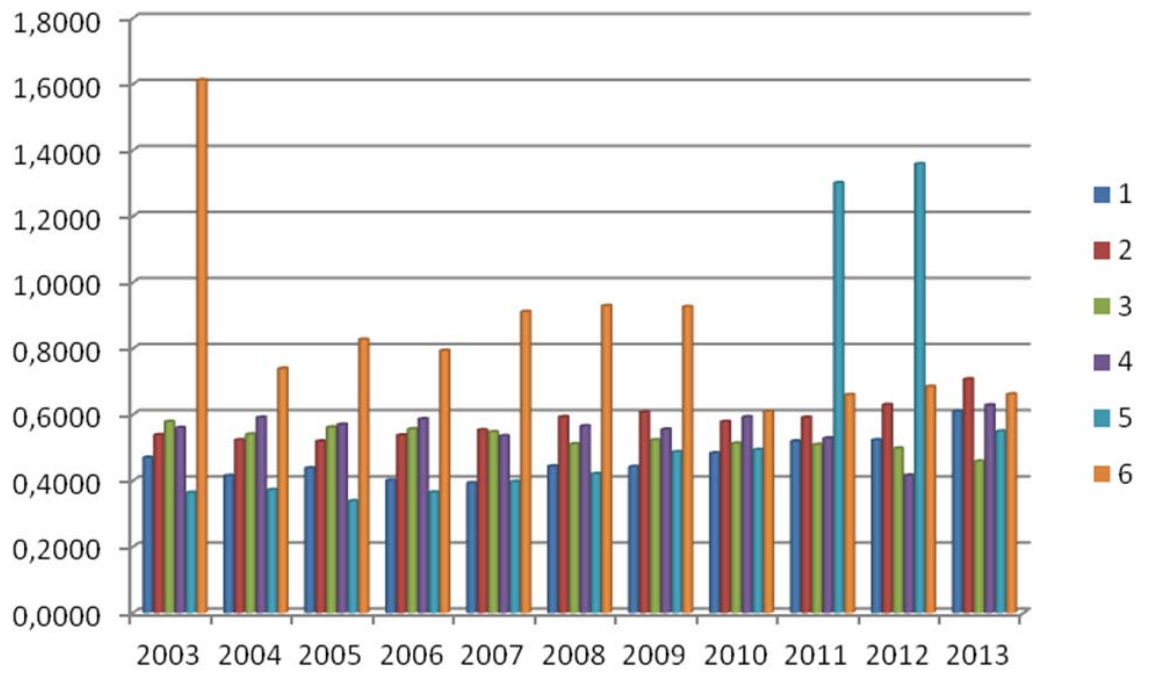

Sourse: own elaboration.

Fig. 2. Average debt by sector 
There are both supportive and contrary opinions as to the influence of sector indebtedness, as we discussed. Brealy et al. (2010) observed the differences in the financial structure of companies in different sectors, for example, intangible-intensive industries tend to have lower debt to tangible assets sectors. However, Myers (1984) stated that the debt is the result of the funding requirements of the company, with little influence of the sector in the composition of its liabilities. Fariñas and Suarez (1996) observed a large heterogeneity between firms in the same sector and therefore the sector would not be decisive in the corporate debt. This is because the firms considered in the sample are classified as industrial.

The analysis of the mean values of debt allows us to draw conclusions about the sector average and the annual evolution experienced by each of the sectors (see Figure 2). This is relevant because different sectors typically have different characteristics. Analyzing the debt-industry relationship giving the determinants of the sector coupled with other variables allows us to determine whether the conclusions drawn from both perspectives coincide.

First, with regard to sector averages, the associated result 6 sector, which corresponds to Technology and Telecommunications (Sector 6), which has a higher average debt for the entire projection period, namely a $85.55 \%$ of debt, compared to other sectors that are close to $50 \%$. For example, the Oil and Energy sector has a $52.89 \%$ of average debt for the period 2003-2013.

Analyzing the evolution of average debt in each of the sectors we can see that the field of Technology and Telecommunications (Sector 6) is the only one that has experienced a significant decrease in debt for the period 2003-2013 (from $161.25 \%$ to $66.15 \%$ debt). Meanwhile, the sector (Sector 3) has seen decreased debt from $57.84 \%$ in 2003 to $45.87 \%$ in 2013. However, the general trend has been an increase debt from 2004 to 2012, especially in the period 2010-2011, in which it rose from $53.22 \%$ to $72.80 \%$. This may have been caused by the economic difficulties experienced by these companies as a result of the economic crisis which could have forced them to incur in order to survive the fall of the activity and the increase in default that has occurred in recent years.

By sector, the most affected by the economic situation has been the Financial and Real Estate Services (Sector 5) which is reflected in the rise of debt from $49.34 \%$ to $130.09 \%$ debt in one year (2010 to 2011). This data reflects the difficult situation faced by real estate companies, which has experienced very significant drop in activity. Note that the data in this sector include, as mentioned above, those related to financial companies, so the companies are mostly real estate. The remaining sectors have been less exposed to the financial situation from the point of view of the level of debt, for example, the Consumer Goods sector (Sector 1) increased its debt from $48.31 \%$ in 2010 to $51.96 \%$ in the same period (2010-2011). This increase is even lower than other exercises. As an example we see that in 2012 it had a foreign debt of $52.29 \%$, while in 2013 it stood at $60.94 \%$.

\section{Conclusion}

In this section we are going to evaluate the results of the analysis of the model we propose (Model IV). So the regressions results show that, indicators of economic profitability (ROA), have a negative relationship with the debt level, so that the more profitable the company, the lower the debt. This is because the greater the ability of the company to generate resources, the less active will be their borrowing. This is in line with that proposed by Rajan and Zingales (1995) who claimed that the higher profitability and business risk would yield lower debt.

On the other hand, the composition of assets or economic structure is equally important when choosing financing. One of the most important principles in business economics is the financial balance, i.e. it is essential to have balance between noncurrent investments and financing for company survival. Therefore companies must finance their investments, noncurrent assets, with long-term financing to not jeopardize this balance.

Finally, the debt of the previous year is something that companies must consider when choosing to be financed by borrowings, this is because the risk exposition will depend on their ability to meet the repayment of debts. Also, the financial institutions will be more positive to provide financial support to companies with small levels of debt than to companies with high levels. In Menendez and Mendez (2013) the relationship between the initial level of debt and the current corporate borrowing is observed.

In the case of the firm size, in the various models analyzed we observed a relationship with debt. In this sense, if the company has bigger size it will be a better guarantee to its creditors. These results are consistent with those obtained by Long and Malitz (1985), Marsh (1982) and Jimenez and Palacín (2006). Furthermore, the size gives more bargaining power to the company, so one obtains better terms in their external financing. Therefore, the costs incurred are lower than those of other smaller companies, i.e., the interest rate differential that 
supports these companies with respect to the interbank is less than that of a company with smaller size and therefore less bargaining power. Again, our results are consistents with the works of Mato (1990) and Otero and Fernandez (2004) which found, evidence of an inverse relationship between the size and the cost of debt in the case of the Spanish industrial companies and SMEs in Galicia. Fariñas and Suarez (1996) also found that smaller companies had less bank debt but that the cost was greater than the larger companies.

Finally, with respect to liquidity ratio we have observed the same influence, i.e., the higher liquidity, the reduced need to borrow. In our case the implications of the theory of rank order or pecking order would be fulfilled and not the theory of optimal leverage or trade-off. The results were consistent with companies with more liquid debt.

For sector we see that there are differences in the level of intangible assets they hold. In general we must highlight the importance of weight of intangibles in economic structure, there are sectors like technology and telecommunications that are intensive in R\&D, while others such as oil and energy have a lower level of intangibles. However, the differences in percentages are not very high because the size of total assets of these companies is very high. It is generally observed as in Rajan and Zingales (1995) and Marsh (1982) that the level of intangible influences the debt. We see that the technology and telecommunications sector has the highest level of intangibles and debt features. However, this relationship is not very significant as between different sectors.

With respect to debt-industry relationship we see that the general trend in all sectors has been to increase debt levels, however, there exists notable difference depending on the varying sector.

To complete the work we have to note that there is a model that can explain the behavior of firms when choosing its sources of funding. On the one hand there are many internal variables to consider, such as investment company, size, profitability, etc. On the other hand, there are external factors such as economic conditions, the financial market, etc. that influence companies but are beyond their control. This is reflected in the subjectivity in decision-making and risk-averse decision making. This subjectivity can make executives who are very risk averse to make completely different financial decisions than other managers with lower risk aversion, even though the firm characteristics are identical. This is consistent with the results obtained by Andrés-Alonso et al. (2000) in which it is stated that debt is not neutral to the separation of ownership and management.

Finally, we note the limitations of the work. Firstly, while financial institutions have different accounting standards, it would be interesting to be able to analyze the determinants of borrowing in these companies. Second, this work only includes the listed companies, this means that we have analyzed only a small percentage of Spanish companies, as approximately $94 \%$ of Spanish companies are considered microenterprises, i.e. companies with less than 10 workers. This means that we have not taken into account the largest proportion of Spanish businesses. Finally, a more disaggregated level of data could have been obtained with more specific conclusions to better analyze the choice of companies across varying financial instruments, however this information is not readily accessible as employers are reluctant to provide more information than is required by accounting standards.

\section{References}

1. Acedo Ramírez, M.A., Calvo, A.J.C. \& Rodríguez Osés, J.E. (2005). Rentabilidades, endeudamiento y coste de de la deuda de las pymes, Análisis empírico de las empresas por tamaños, Revista Europea de Dirección y Economía de la Empresa, 14 (4), pp. 185-200.

2. Andrés-Alonso, P., Azofra-Palenzuela, V. \& Rodríguez-Sanz, J. (2000). Endeudamiento, Oportunidades de Crecimiento y Estructura Contractual: Un Contraste Empírico para el caso español, Investigaciones Económicas, 24 (3), pp. 641-679.

3. Ayuso, J. (2013). Un análisis de la situación del crédito en España, Boletín Económico del Banco de España, pp. 81-99.

4. Bradley, M., Jarrell, G.A. \& Han Kim, E. (1984). On the Existence of an Optimal Capital Structure: Theory and Evidence, The Journal of Finance, 39 (3), pp. 857-878.

5. Brealy, R., Myers, S.C. \& Allen, F. (2010). Principios de Finanzas Corporativas, Méjico: The McGraw-Hill.

6. Castanias, R. (1983). Bankruptcy Risk and Optimal Capital Structure, The Journal of Finance, 38 (5), pp. 1617-1635.

7. Fariñas, J.C. \& Suárez, C. (1996). La Empresa Industrial en la Década de los Noventa: Financiación, Programa de Investigaciones Económicas, pp. 1-43. Fundación Empresa Pública.

8. Fernández Ramos, M.Y., Rojas Conde, M. \& David Zuliani, G. (2004). Contrastación de la Teoría del "Pecking Order": El caso de las Empresas Españolas.

9. Gil de Albornoz, B. \& Giner, B. (2013). Predicción del fracaso empresarial en los sectores de construcción e inmobiliarios: Modelos generales vs específicos, Universia Business Review, pp. 118-131. 
10. Gude Redondo, A. (2014). Determinantes del Endeudamiento: Aplicación al sector español de aguas envasadas, Oviedo: HiFer Editor.

11. Harris, M. \& Raviv, A. (1991). The Theory of Capital Structure, The Journal of Finance, 46 (1), pp. $297-355$.

12. Jiménez Naharro, F. \& Palacín Sánchez, M.J. (2006). Determinantes de la estructura financiera de la empresa, Revista Europea de Dirección y Economía de la Empresa, 16 (4), pp. 9-24.

13. Hull, Robert M. (2007). A Capital Structure Model, Investment Management and Financial Innovations, 4 (7), pp. 8-24.

14. Hull, Robert M. (2010). A Capital Structure Model with Growth, Investment Management and Financial Innovation, 7 (4), pp. 55-69.

15. Hull, Robert M. (2012). A Capital Structure Model with Wealth Transfers, Investment Management and Financial Innovation, 9 (3), pp. 19-32.

16. Hull, Robert M. (2014). A Capital Structure Model (CSM) with Tax Rate Changes, Investment Management and Financial Innovations, 11 (3), 2014, pp. 8-21.

17. Kraus, A. \& Litzenberger, R.H. (1973). A State-Preference Model of Optimal Financial Leverage, The Journal Of Finance, 28 (4), pp. 911-922.

18. Long, M.S. \& Malitz, I.B. (1985). Investment Patterns and Financial Leverage, In B.M. Friedman, \& ed., Corporate Capital Structures in the United States, University of Chicago Press, pp. 325-352.

19. Marsh, P. (1982). The Choice Between Equity and Debt: An Empirical Study, The Journal of Finance, 37 (1), pp. 121-144.

20. Mato, G. (1988). Investment Demand at the Firm Level: the Case of Spain, Recherches Economiques de Louvain, 54, pp. 325-336.

21. Mato, G. (1989). Inversión, Coste de Capital y Estructura Financiera: Un estudio empírico, Moneda y Crédito (Segunda Época), pp. 177-201.

22. Mato, G. (1990). Un análisis econométrico de la política de endeudamiento de las empresas con datos de panel. Investigaciones Económicas (Segunda Época), 14 (1), pp. 63-83.

23. Menéndez, A. \& Méndez, M. (2013). La evolución del endeudamiento de las empresas no financieras españolas desde el inicio de la crisis. Un análisis desagregado, Boletín Económico del Banco de España, pp. 81-87.

24. Miralles, J.L. \& Daza, J. (2011). La reestructuración de las Cajas de Ahorro en el Sistema Bancario español, pp. 507-557.

25. Miller, M. (1977). Debt and Taxes, Journal of Finance, 32 (2), pp. 261-275.

26. Modigliani, F. \& Miller, M. (1958). The cost of capital, corporation finance and the theory of investment, The American Economic Review, 48 (3), pp. 261-297.

27. Modigliani, Fred and Merton Miller. (1963). Corporate Income Taxes and Cost of Capital: A Correction, American Economics Review, 53 (3), pp. 433-443.

28. Montero, R. (2011). Efectos fijos o aleatorios: test de especificación, Documentos de Trabajo en Economía Aplicada, Universidad de Granada, España.

29. Myers, S.C. (1984). Capital Structure Puzzle, Journal of Finance, 39 (3), pp. 575-592.

30. Myers, S. and N. Majluf. (1984). Corporate Financing and Investment Decisions When Firms Have Information Investors Do Not Have, Journal of Financial Economics, 13, pp. 187-221.

31. Myers, S.C. (2001). Capital Structure, The Journal of Economic Perspectives, 15 (2), pp. 81-102.

32. Oliveras, E. \& Moya, S. (2005). La utilización de los datos sectoriales para complementar el análisis de los estados financieros, Revista de Contabilidad y Dirección, 2, pp. 53-69.

33. Otero González, L. \& Fernández López, S. (2004). Aproximación a la actividad financiera de la pyme gallega, La empresa y su entorno, pp. 345-355. Ourense.

34. Rajan, G.R., \& Zingales, L. (1995). What Do We Know about Capital Structure? Some Evidence from International Data, The Journal of Finance, 50 (5), pp. 1421-1460.

35. Rodríguez-Masero, N., Mateo Castellano, M., Medrano Teba, A. \& Rodríguez Herrera, S. (2013). Análisis y Evolución de la Estructura de Deuda de las empresas que han cotizado en la Bolsa de Madrid durante el periodo 2006-2011, European Scientific Journal, 9 (4), pp. 270-294.

36. Sánchez-Vidal, J. \& Marín Ugedo, J.F. (2005). Preferencias Dinámicas de Financiación de las Empresas Españolas: Nueva Evidencia de la Teoría de la Jerarquía, Review of Quantitative Finance and Accounting, 25 (4), pp. $341-355$.

37. Segura, J., Toledo \& Liliana. (2003). Tamaño, Estructura y Coste de Financiación de las empresas manufactureras españolas, Investigaciones Económicas, 27 (1), pp. 39-69.

38. Titman, S. \& Wessels, R. (1988). The Determinants of Capital Structure Choice, The Journal of Finance, 43 (1), pp. $1-19$.

39. Wald, J.K. (1999). How firm characteristics affect Capital Structure: An International Comparison, The Journal of Financial Research, 22 (2), pp. 161-187. 